\title{
Electrical and Mechanical Effects of Carbon Powder in F and C Class Fly Ash Reinforced Mortars
}

\author{
Hacer Uzunalioglu ${ }^{*} \quad$ Adem Ahıskalı $^{2} \quad$ Hakan Caglar $^{3} \quad$ Salih Yazıcıoglu $^{4}$ \\ 1.Material Science And Engineering, Kastamonu University, Kastamonu, Turkey \\ 2.Engineering and Architecture Faculty, Civil Engineering, Kastamonu University, Kastamonu ,Turkey \\ 3.Faculty of Engineering and Architecture / Civil Engineering, Ahi Evran University, Kırşehir, Turkey \\ 4.Engineering and Architecture Faculty, Civil Engineering, Gazi University, Ankara, Turkey
}

\begin{abstract}
This study was carried out to investigate the effects of carbon powder on the electrical conductivity and mechanical properties of fly ash reinforced mortars used as mineral additives. Samples were created by replacing CEM I 42.5 $\mathrm{R}$ cement, water and Cen standard sand with $0.5 \%, 1 \%, 3 \%$ carbon powder by weight. Class F and Class C fly ash were added separately at the rate of $10 \%$ and $20 \%$ by weight of cement to the formed carbon dust series. 20 different series were created with the reference sample. Electrical resistivity measurements were made to the oven dry and natural humid conditions of the samples that completed their 7,28 and 56 days curing period. The physical properties of the samples were determined and bending and compressive strength tests were made. The results obtained were evaluated and it was observed that with the increase of the carbon dust ratio compared to the reference sample, the electrical conductivity ratio increased, but the conductivity decreased depending on the time. It has been observed that the $\mathrm{F}$ class fly ash combination series are more conductive than the $\mathrm{C}$ class combination series. It was observed that the compressive and tensile strength values of $\mathrm{F}$ and $\mathrm{C}$ class fly ash carbon dust free samples increased with time. Carbon dust has been shown to increase compressive strength in fly ashless series. There was an increase in the 56th day reading in the tensile strength. It was observed that $\mathrm{F}$ class increased tensile and compressive strength in fly ash and carbon dust combination series.
\end{abstract}

Keywords: Carbon dust, F class fly ash, C class fly ash, Electrical conductivity.

DOI: $10.7176 / \mathrm{CER} / 13-2-02$

Publication date: April $30^{\text {th }} 2021$

\section{Introduction}

Human beings have constantly developed the types of materials and application methods that they use in structures. Because of its strength and long-term use, concrete has been the most used material as a carrier element in the construction sector for many years. With the discovery of electricity and progress in technology, our expectations in structures have also changed over time. Many studies have been carried out and are still being carried out on concrete and mortar samples to meet our expectations. For this purpose, researches such as reducing its cost, strengthening its weaknesses, etc. by adding many materials into concrete have been carried out.

With today's technology, it is possible to give conductivity property to concrete, which is an insulator. Objects that convey electrical energy and heat energy are called conductive materials in the literature. It is known that electrical conductivity is carried out by atomic-sized electron or electron spaces within the material. Huang, B.S. et al. (2009). Various fibres and aggregates are added to the concrete to give it conductivity properties.

By using materials such as carbon powder, aluminium powder, graphite powder, carbon fibre, steel fibre and aggregates with high iron content, steel wool, steelmaking slag, the conductivity properties of concrete are also increased. Gopalakrishnan, K. et al. (2015). By conveying an electric current through the conductive concrete, icing is prevented by heating the concrete or the negative effects of the existing icing are eliminated. Tuan, C. Y. (2004). Conductive concrete technology is used in many fields as well as de-icing. These usage areas can be listed in structures developed for the protection of electrical systems and electronic components, in the formation of antistatic floors in the electronic industry, in cathodic protection in reinforced concrete structures and in the production of smart concrete, etc.Bertolini, L. et al. (2004); Chung, D. D. L. (2004).

In this sense, D.D.L Chung, one of the professors of SUNY (State University of New York)/Buffalo, was the first to use the term smart concrete as well as smart technological tools. Smart concrete was developed and patented by Chung, based on the need to monitor concrete as a smart material suitable for use in the building industry. Demirel, B.(2006) noted that the concrete obtained by adding small amounts of microscopic conductive short carbon fibre (at a least bulk by $0.2 \%-0.5 \%$ ) into the concrete is smart concrete. It shows that when the smart concrete formed by carbon fibre mixture is deformed or stretched, the contact effect between fibre and cement matrix can be determined by examining the volumetric electrical resistivity. In addition to carbon fibre in concrete, the electrical and mechanical effect of carbon powder makes a sensation.

The use of Activated Carbon for industrial purposes was started at the end of 18th century by the Swedish origin German Pharmacist and Chemist Karl Wilhelm Scheele. Wikipedia, (2021), with the absorption of gases using charcoal. It is known that Russian academic Lovits used charcoal to eliminate the colour of a solution of 
tartaric acid containing organic matter. Stoeckli \& Kraehenbuehl (1984). It was used as a decolourizer in the sugar industry in England in 1794. Kodlec, O. (1979). Activated carbon is used in a wide range of areas, including in the industry, purification and refinement of gases, in separation of mixtures, in purification processes in the food industry, in water and wastewater treatment, in carbon additive in the metal industry, in protective clothing in the defence industry, in explosives in the weapon industry and making bombs to silence electronic systems and in the health sector. Currently, it is strategically important for the future of our country, as it has quite suitable areas of use for the defence industry. In summary, activated carbon, which we use for various purposes in daily life, is an indispensable substance. Stoeckli \& Kraehenbuehl (1984). Sezer et al.(2019) reported in their work on the production of 3D parts in complex form easier, lower cost and faster than traditional methods with additive manufacturing (IR) technology that the strength of the part can be significantly improved with $6 \mathrm{~mm}$ long carbon fibre reinforcement, and the use of reinforcement materials in the form of either powder or short $(>3 \mathrm{~mm})$ fiber as additives increases the mechanical strength to a limited degree in the literature. Boğa, A.R. (2017) searched the effects of steelmaking slag and carbon fibre on the mechanical and electrical conductivity properties of mortars when used together or separately. According to the results obtained, it was observed that electrical conductivity properties improved when steelmaking slag and carbon fibre were used together in mortar samples. Dehghanpour (2019) examined the results by conducting mechanical, electrical and impact tests of electrically conductive concrete. According to the results of the test, samples containing nano carbon black, carbon fibre and steel fibre in different functions improve mechanical properties. The electrical resistances of all electrically conductive concrete samples mixed with carbon fibre are decreased compared to the control sample, and this feature became clearer as the carbon fibre content ratio increased.

Fly ash, which is abundant in our country, is a valuable type of waste derived from coal-fired thermal power plants. The use of mineral additives has increased with the detection that it lowers the cost by reducing the production energy in Portland cement concrete. Subaş1, S. (2009). Due to their fine-grained and pozzolanic reaction, mineral additives improve the mechanical properties of concrete. Aruntaş, H.Y. (2006). This study allowed comparison of $\mathrm{F}$ and $\mathrm{C}$ Class fly ashes.

\section{Material And Method}

\subsection{Materials}

2.1.1. Cement

CEM I 42.5 R Portland cement which is compatible with TS EN 197-1, with grain density $3.15 \mathrm{~g} / \mathrm{cm} 3$ and whose specific surface is $3740 \mathrm{~cm}^{2} / \mathrm{g}$ was used in the study.

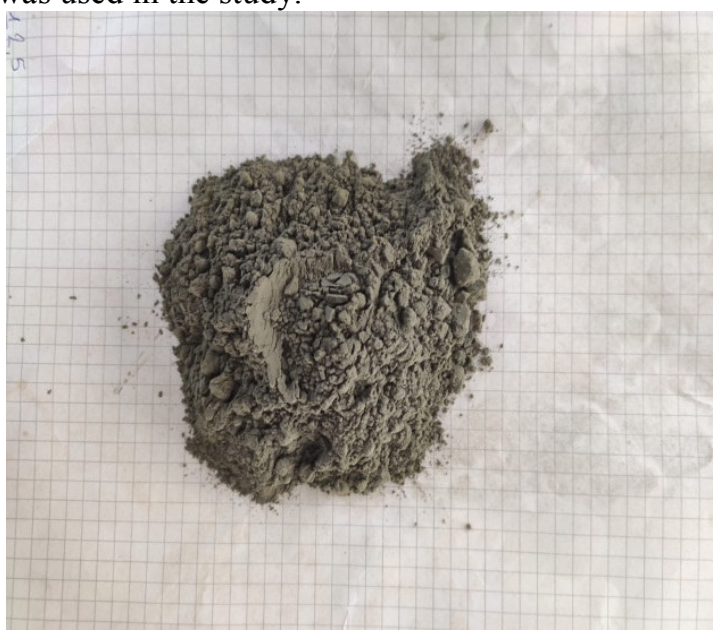

Figure 2.1. CEM I 42.5 R Portland cement. 
Table 2.1.Chemical and physicalspecifications of CEM I 42.5 R Portland cement.

\begin{tabular}{|c|c|c|c|c|c|}
\hline $\begin{array}{l}\text { Chemical } \\
\text { Specifications } \\
\end{array}$ & & & $\begin{array}{l}\text { Physical } \\
\text { Specifications } \\
\end{array}$ & & \\
\hline Component & CEM I 42.5R & TS EN 197-1 & Specification & Value & TS EN 197-1 \\
\hline $\mathrm{CaO}$ & 63,93 & & Starting Socket & 141 & $\geq 60$ \\
\hline $\mathrm{SiO}_{3}$ & 19,49 & $\mathrm{C}+\mathrm{S} \geq \% 50$ & Socket Finish & 202 & - \\
\hline $\mathrm{Al}_{2} \mathrm{O}_{3}$ & 4,36 & - & Density $(\mathrm{g} / \mathrm{cm} 3)$ & 3,15 & - \\
\hline $\mathrm{Fe}_{2} \mathrm{O}_{3}$ & 3,40 & - & $\begin{array}{l}\text { Blaine } \\
(\mathrm{cm} 3 / \mathrm{g})\end{array}$ & 3866 & - \\
\hline $\mathrm{MgO}$ & 1,67 & Lim. $\leq \% 5$ & $\begin{array}{l}32 \mu \text { Remainder on the } \\
\text { Sieve }\end{array}$ & 7.7 & - \\
\hline $\mathrm{Na}_{2} \mathrm{O}$ & 0,27 & - & $\begin{array}{l}90 \mu \text { Remainder on the } \\
\text { Sieve }\end{array}$ & 0.1 & - \\
\hline $\mathrm{K}_{2} \mathrm{O}$ & 0,67 & - & $\begin{array}{ll}\text { Total } & \text { Volume } \\
\text { Expansion } & \end{array}$ & 1 & $\leq 10 \mathrm{~mm}$ \\
\hline Loss in Ignition & 2,91 & $\leq \% 5$ & Expansion & - & - \\
\hline Insoluble Matter & 0,32 & $\leq \% 5$ & 2 days endurance & 28.1 & $\geq 20,0 \mathrm{Mpa}$ \\
\hline Sulphur Trioxide & 28.1 & $\geq 20,0 \mathrm{Mpa}$ & 7 days endurance & 45.7 & - \\
\hline Chloride (Cl- ) & 0,0089 & $\leq \% 0,1$ & 28 days endurance & 56.8 & $\begin{array}{l}\geq \quad 42,5 \quad \mathrm{Mpa} \\
\leq 62,5 \mathrm{MPa}\end{array}$ \\
\hline
\end{tabular}

\subsubsection{Aggregate}

In the preparation of the mortar samples, Cen Standard Sand compatible with TS EN 196-1 was used. Relative density is $2.60-2.65 \mathrm{~g} / \mathrm{cm}^{3}$.

Table 2.2. Technical specifications of Cen Standard Sand

\begin{tabular}{ll}
\hline Aperture Size (mm) & $\begin{array}{l}\text { Cumulative Remainder } \\
(\%)\end{array}$ \\
\hline 2,00 & 0 \\
1,6 & $7 \pm 5$ \\
1 & $33 \pm 5$ \\
0,5 & $67 \pm 5$ \\
0,16 & $87 \pm 5$ \\
0,08 & $99 \pm 1$ \\
2 & 0 \\
\hline
\end{tabular}




\subsubsection{Fly Ash}

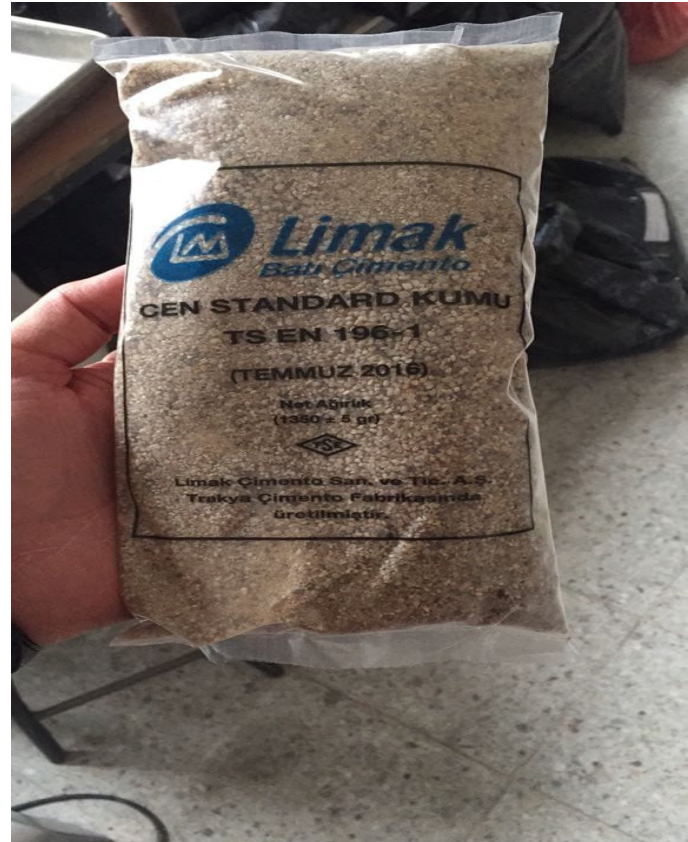

Figure 2.2. Cen Standard Sand

Fly ash is a kind of waste derived from coal-fired thermal power plants. Although there is an average annual production of fly ash of up to 13 million in power plants in our country, it is estimated that this rate will increase in the future, taking into account the energy need.

Several researches have been conducted to take advantage of fly ash like every industrial waste and it is widely used as additive in cement concrete. Türker, P. et al. (2009).

\subsubsection{Classification of fly ashes}

In the classification of fly ash, ASTM C 618 [19] and TS EN 197-1 standards are mainly taken as a basis in accordance with the percentage of chemical component. According to ASTM C 618 standard, fly ashes are divided into $\mathrm{F}$ and $\mathrm{C}$ classes.

Table 2.3.Fly Ash Chemical Analysis

\begin{tabular}{lll}
\hline Fly Ash & $\begin{array}{l}\text { C Class } \\
\text { (Soma) }\end{array}$ & $\begin{array}{l}\text { F Class } \\
\text { (Çayırhan) }\end{array}$ \\
\hline $\mathrm{SiO}_{2}$ & 42,82 & 50,98 \\
$\mathrm{Al}_{2} \mathrm{O}_{3}$ & 20,82 & 13,11 \\
$\mathrm{Fe}_{2} \mathrm{O}_{3}$ & 4,57 & 9,74 \\
$\mathrm{~S}+\mathrm{A}+\mathrm{F}$ & 68,21 & 73,83 \\
$\mathrm{CaO}$ & 23,45 & 11,82 \\
$\mathrm{MgO}$ & 1,74 & 3,91 \\
$\mathrm{SO}_{3}$ & 1,47 & 3,94 \\
$\mathrm{~K}_{2} \mathrm{O}$ & 1,31 & 1,91 \\
$\mathrm{Na}_{2} \mathrm{O}$ & 0,32 & 2,71 \\
$\mathrm{KK}$ & 2,75 & 0,86 \\
$\mathrm{Cl}$ & 0,010 & 0,014
\end{tabular}

\subsubsection{C class fly ash}

Class $\mathrm{C}$ fly ashes are the ashes produced from lignite or semi-bituminous coal, with a total $\mathrm{SiO} 2+\mathrm{A} 12 \mathrm{O} 3+\mathrm{Fe} 2 \mathrm{O} 3$ amount of more than $50 \%$; and besides the pozzolanic feature they also have binding features as well; since $\mathrm{CaO}>10 \%$, these ashes are also called high calcareous fly ash. The fly ash from Soma Thermal Power Plant was used as Class $\mathrm{C}$ in the mortar samples. Its specific weight is $2.41 \mathrm{~g} / \mathrm{cm}^{3} ; 90 \mu \mathrm{m}$ sieve residue (\%) is $33.7 ; 45 \mu \mathrm{m}$ sieve balance $(\%)$ is 52.6 . 


\subsubsection{F class fly ash}

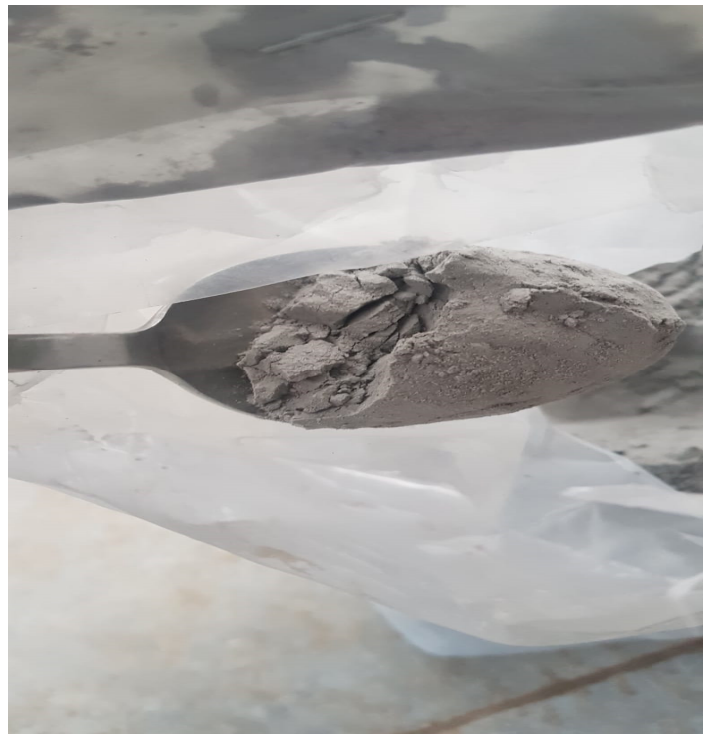

Figure 2.3. C class fly ash

Class F fly ashes are the ashes produced from lignite or semi-bituminous coal, with a total $\mathrm{SiO} 2+\mathrm{A} 12 \mathrm{O} 3+\mathrm{Fe} 2 \mathrm{O} 3$ amount of more than $70 \%$ and have pozzolanic feature; since its $\mathrm{CaO}$ percentage is below $10 \%$ it is also known as low calcareous. The fly ash from Çayırhan was used as Class $\mathrm{C}$ in the mortar samples. Its specific weight is $2.36 \mathrm{~g} / \mathrm{cm}^{3} ; 90 \mu \mathrm{m}$ sieve residue $(\%)$ is $6.7 ; 45 \mu \mathrm{m}$ sieve balance $(\%)$ is 24.5 .

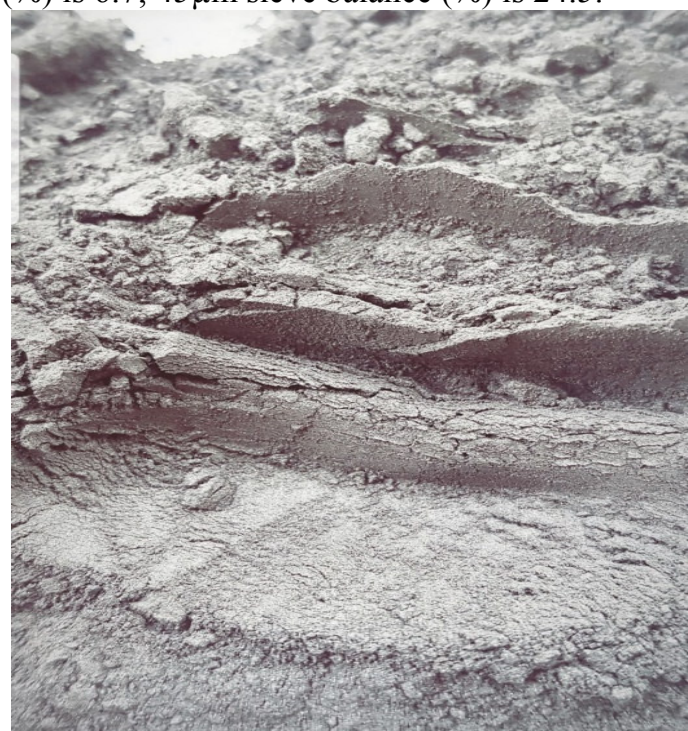

Figure 2.4. F class fly ash

\subsubsection{Carbon Powder}

Activated carbon acquires different chemical activity and physicochemical properties depending on the source from which it is obtained. It can adsorb a wide variety of molecules on its inner surface. Jaroniec \& Choma (1986). In an Ideal activated carbon, the pores are around $0.2-1.0 \mathrm{~cm}^{3} \mathrm{~g}-1$. Although the surface area is in the range of 400-1000 $\mathrm{m}^{2} \mathrm{~g}-1$, This value can be exceeded in special purpose productions. Morgan \& Fink (1989). Pore sizes vary from 0.3 to thousands of nanometers.

According to its shape and size, activated carbon is divided into four groups as powder, granular, filamentous and fabric. Küçükgül, E.Y. (2004). Powdered activated carbon (PAC): These are predominantly powdered carbons smaller than $0.18 \mathrm{~mm}$. Mainly used in liquid phase applications and flue gas treatment. 


\subsubsection{Water}

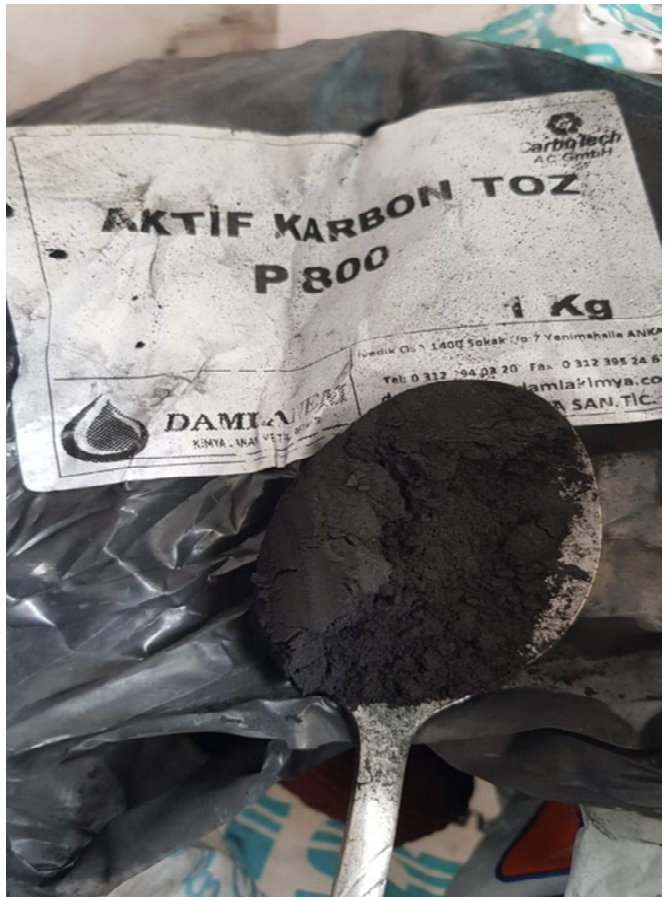

Figure 2.5. Carbon Powder

Yenimahalle/Ankara city water supply was used in the tests.

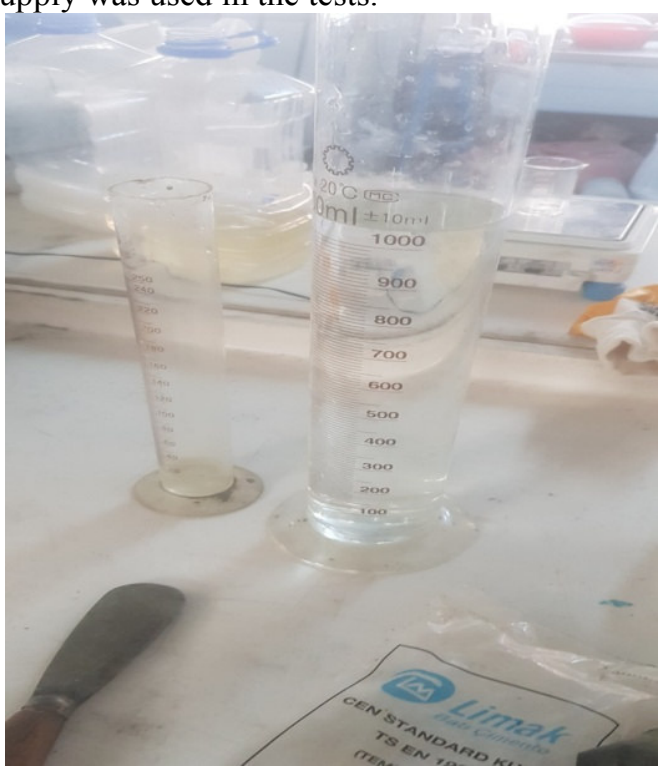

Figure 2.6. Water

\subsection{Method}

In this study, 20 types of samples were created as water, CEM I 42,5 R cement as carbon powder reinforced at $0.5 \%, 1 \%, 3 \%$ by weight of aggregate to the Cen Standard Sand mix and F and C class fly ash combination at rates of $10 \%$ and $20 \%$ and monocoque as a substitute for cement. In all mixtures, the water/cement ratio was determined to remain in the range of $220 \mathrm{~mm}-230 \mathrm{~mm}$ in the Spreading Table Test in line with TS EN 12350-5. In order to reduce the margin of error, 3 samples were prepared with dimensions of $4 \times 4 \times 16 \mathrm{~cm}$ and for each series. The oven dry and electrical resistivity to natural humid conditions measurements of the samples that completed the 7.28 and 56-days curing time were made and the data obtained are interpreted. Compressive strength and flexural strength of all samples were tested. 


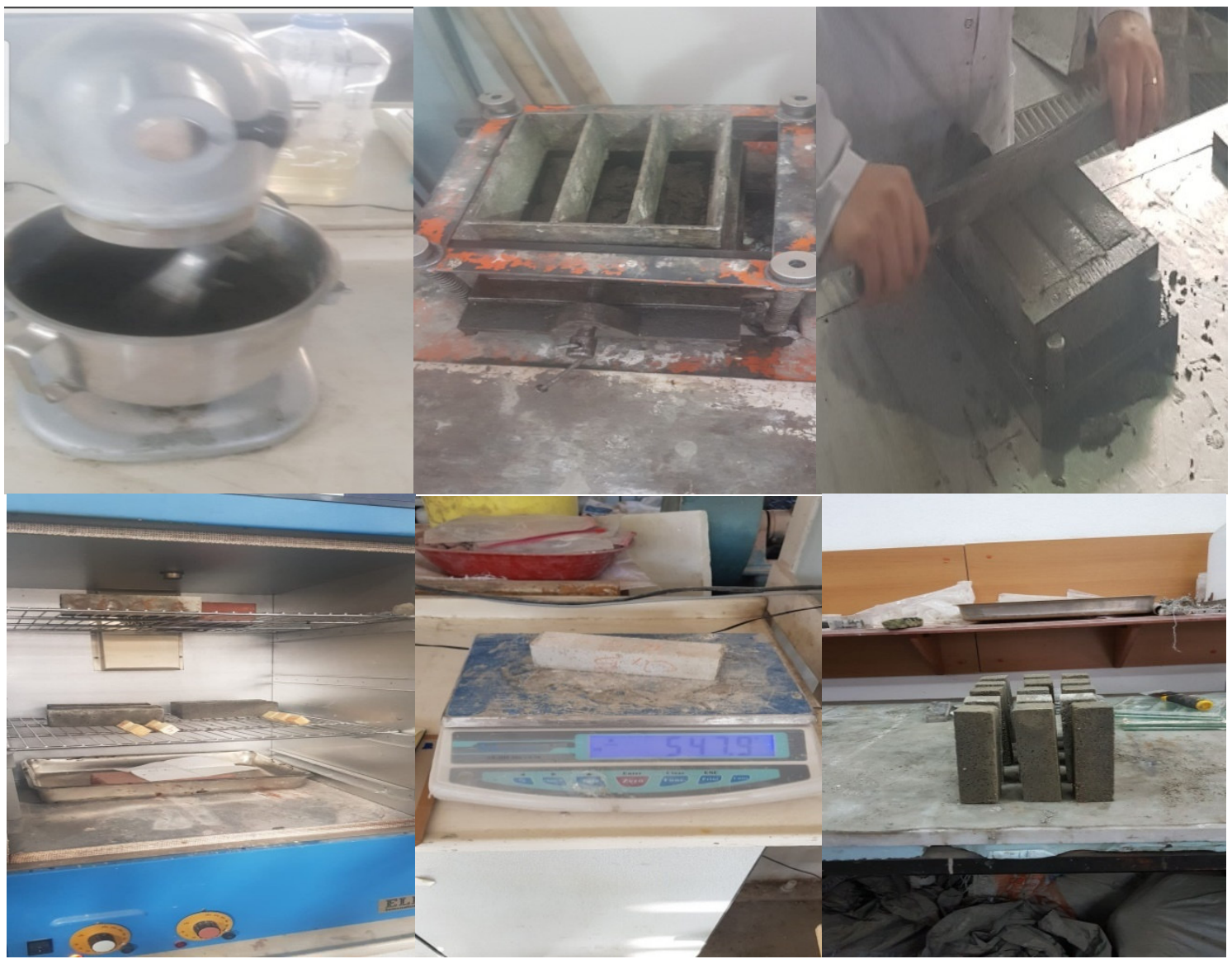

Figures 2.7. Photos of the experiment stages.

\subsubsection{Compressive Strength Test}

A compressive strength test was conducted as a dry oven for samples that completed 7.28 and 56-day treatments. From each sample, harvesting was made in three series and the results were averaged. Tests were conducted in the Concrete Laboratory of Gazi University, Faculty of Technology, Department of Civil Engineering.

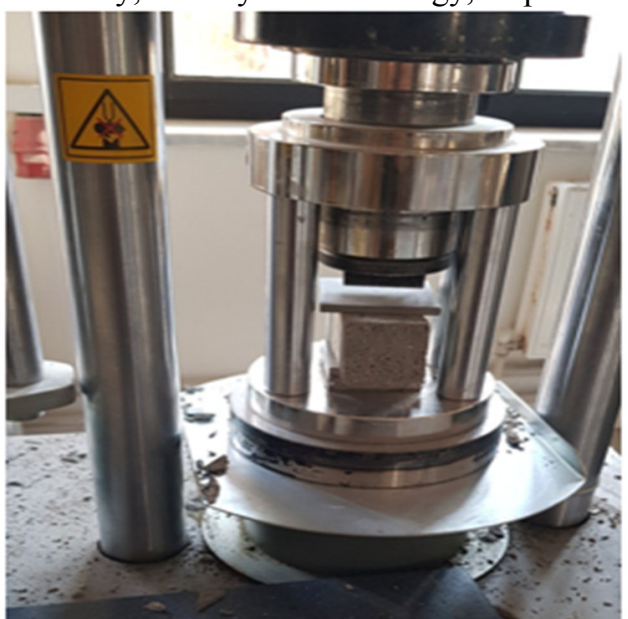

Figure 2.8.Compressive Strength Test

\subsubsection{Tensile Strength Test}

A tensile strength tests was conducted as a dry oven for samples that completed 7.28 and 56-day treatments. From each sample, harvesting was made in three series and the results were averaged. Tests were conducted in the Concrete Laboratory of Gazi University, Faculty of Technology, Department of Civil Engineering. 


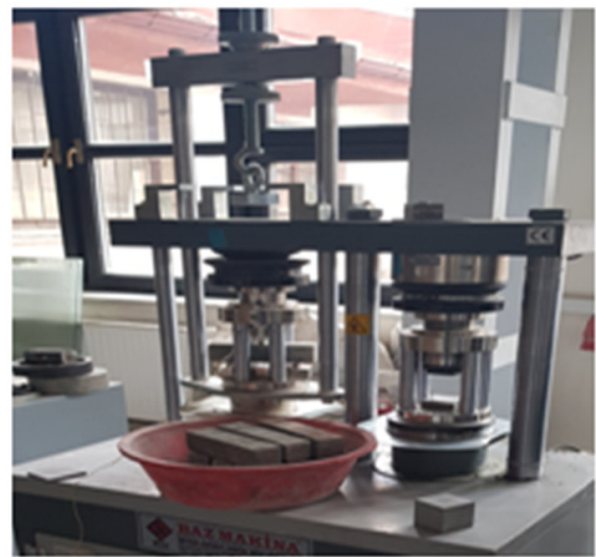

Figure 2.9.Tensile Strength Test

\subsubsection{Electrical Resistivity Measurement}

Measurements were conducted with RCON brand Electrical Resistivity Meter. Before measuring the samples, electrical resistivity was measured with a conductive material of $1 \omega$, and it was observed that the Resistance Meter measured correctly before each measurement. After completing the curing time, samples prepared for pressure and tensile strength tests were measured in oven dry and natural moisture. The sockets of the Resistance Meter are connected to the tables and the measurement is performed by placing the sponges moistened at the same rate each time between the tables and the sample. The results of the samples prepared in three series were calculated using the

$$
R=\frac{\rho L}{A}
$$

formulation and their averages were taken.

$\mathrm{R}=$ Resistance $(\mathrm{ohm})$

$\rho=$ Resistivity (ro)

$\mathrm{L}=$ Length of the sample $(\mathrm{cm})$

$\mathrm{A}=$ Surface area of the sample $\left(\mathrm{cm}^{2}\right)$

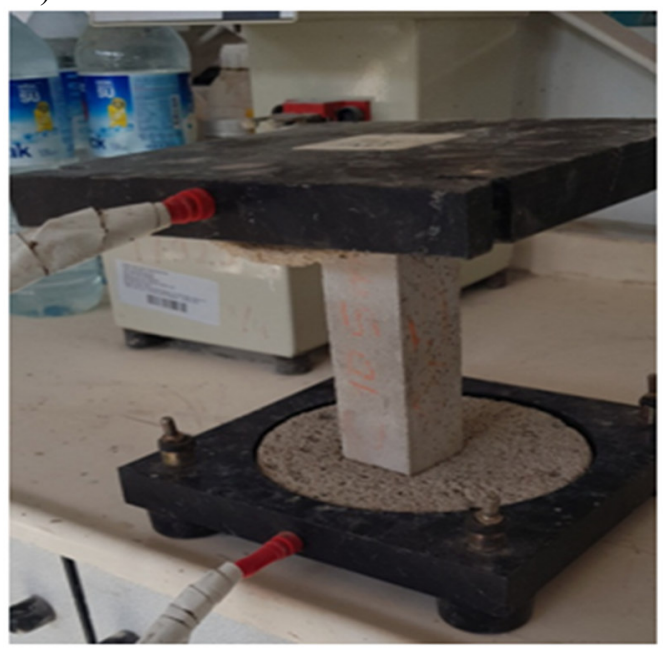

Figure 2.10.Electrical Resistivity Measurement

\section{Results And Findings}

\subsection{Electrical Resistivity Measurement Results}

According to electrical resistivity measurement, no critical effect was observed in C-Class fly ash and carbon powder combination samples compared to the reference sample. Electrical resistivity increased depending on the time. 56-day samples showed an increase in electrical conductivity due to an increase in the ratio of carbon powder (Table 3.1). The best result has been obtained from a Class $\mathrm{C}$ fly ash-free 3\% carbon dust sample. 
Table 3.1.Electrical resistivity measurements of Class $\mathrm{C}$ fly ash and carbon powder combinations.

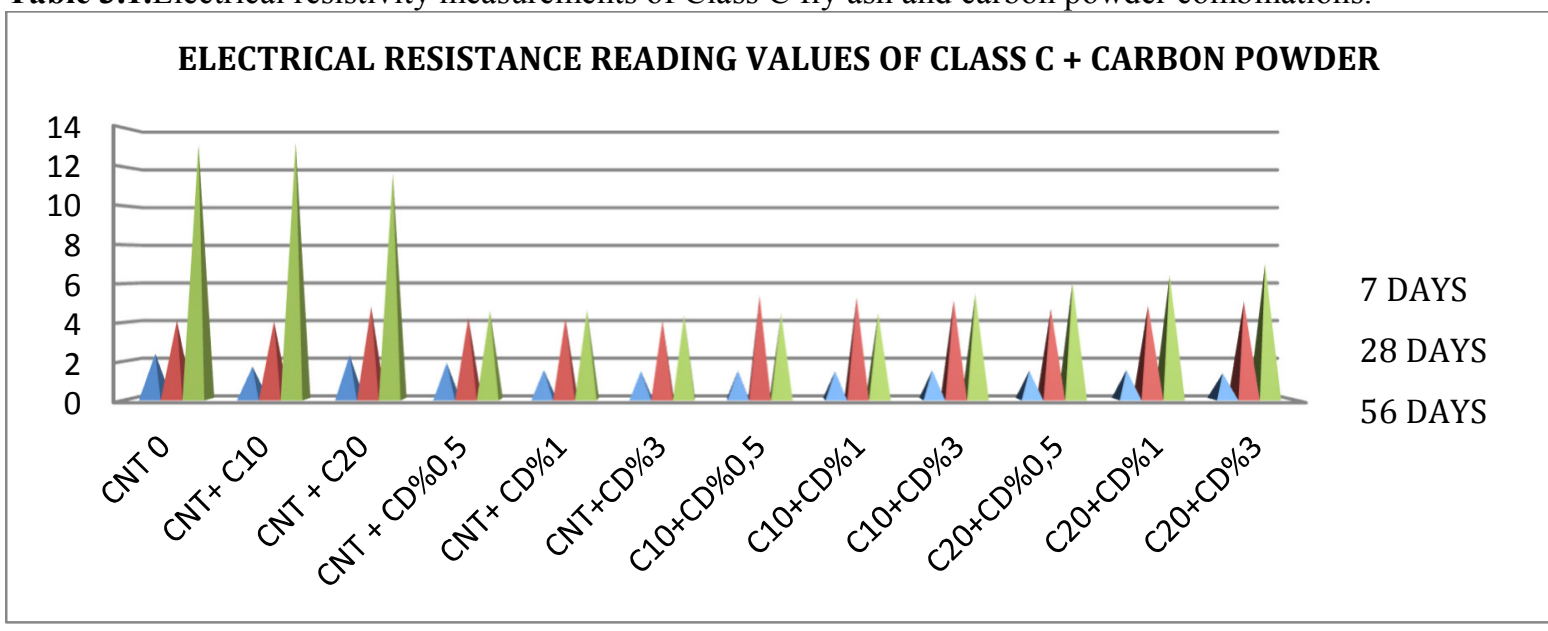

According to the electrical resistivity measurement, an increase in electrical conductivity was observed in F class fly ash and carbon powder combination samples compared to the reference sample (Table 3.2). Electrical resistivity increased depending on the time. The best result was obtained from the sample with $20 \% \mathrm{~F}$ class fly ash and $3 \%$ carbon powder.

Table 3.2.Electrical resistivity measurements of Class F fly ash and carbon powder combinations.

\section{ELECTRICAL RESISTANCE READING VALUES OF CLASS F + CARBON POWDER}

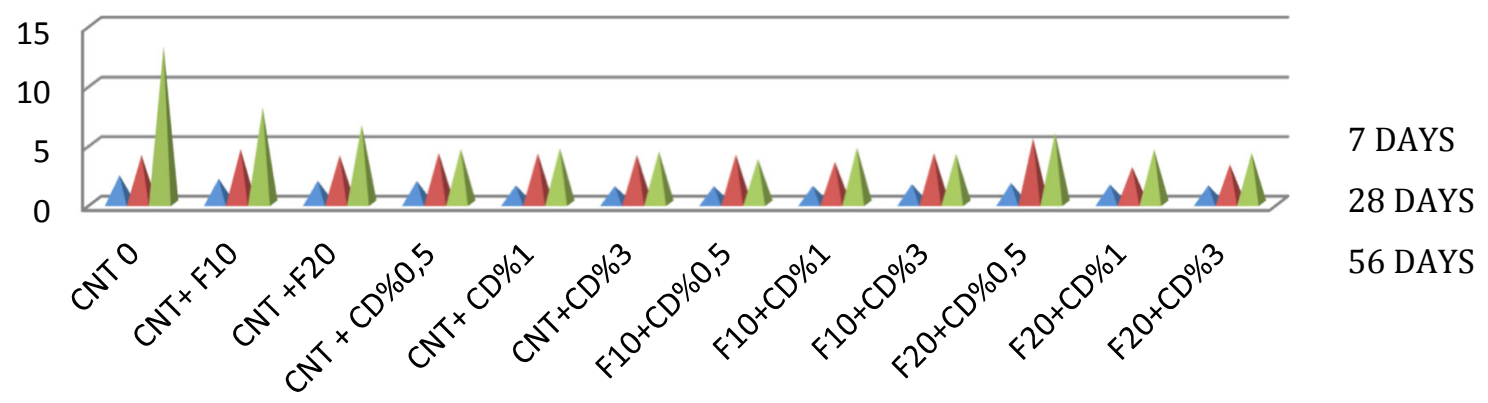

In the electrical resistivity measurements, it was seen that the mortar samples of carbon powder made conductive compared to the reference sample. The best result was obtained from combinations of fly ash with a ratio of $10 \%$ and carbon powder with a ratio of $0.5 \%$ (Table 3.3). It has been concluded that $\mathrm{F}$ Class is more conductive compared to C Class in carbon powder and fly ash combinations.

Table 3.3. Electrical resistivity measurements of fly ash and carbon powder combinations

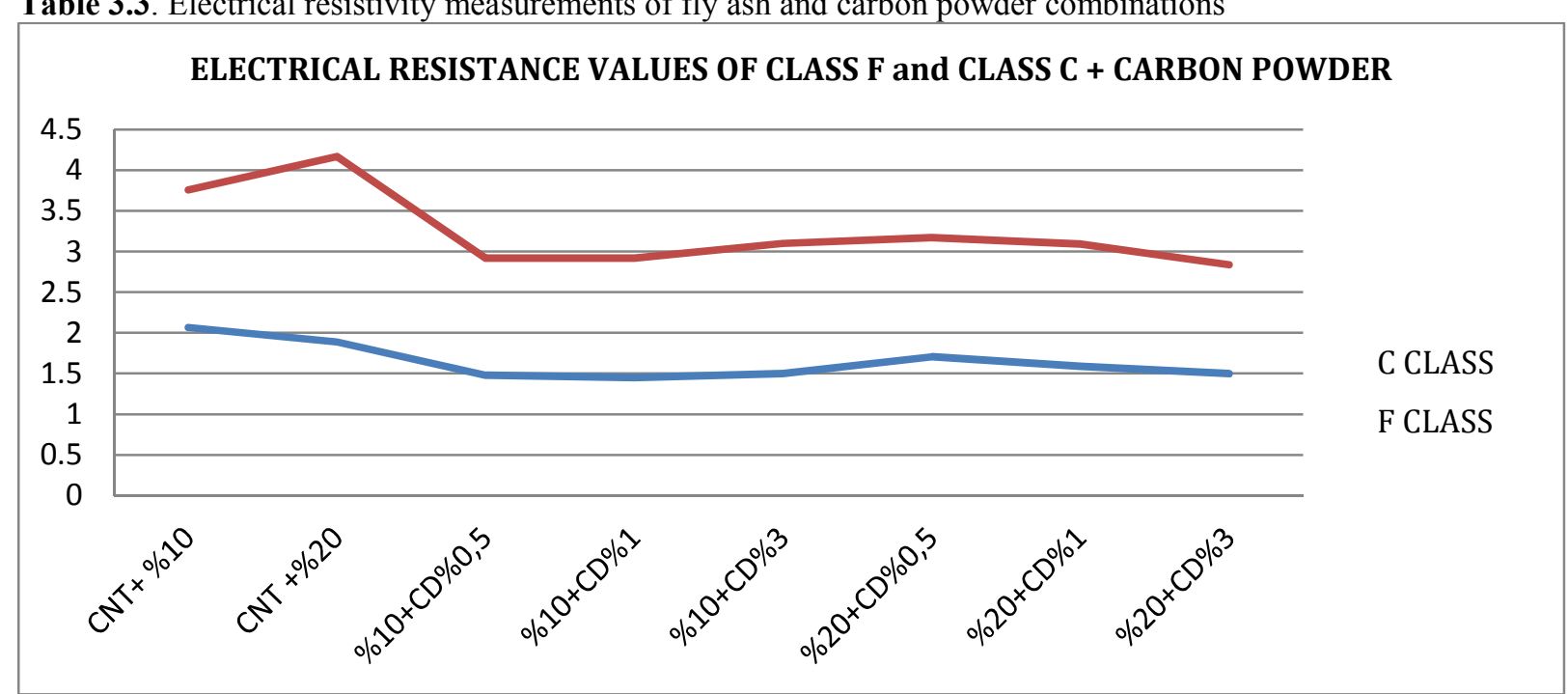




\subsection{Compressive Strength Test Results}

The only sample in the series with no fly ash that showed an increase compared to the reference sample was obtained from CNT $+\mathrm{CD} 0.5 \%$ (Table 3.4). Although there was an increase in the 7 . and 28. day series as the rate of carbon powder increased, it was observed that there was a decrease in the compressive strength in the 56 . day series.

Table 3.4.Compressive strength test results of control (reference) samples

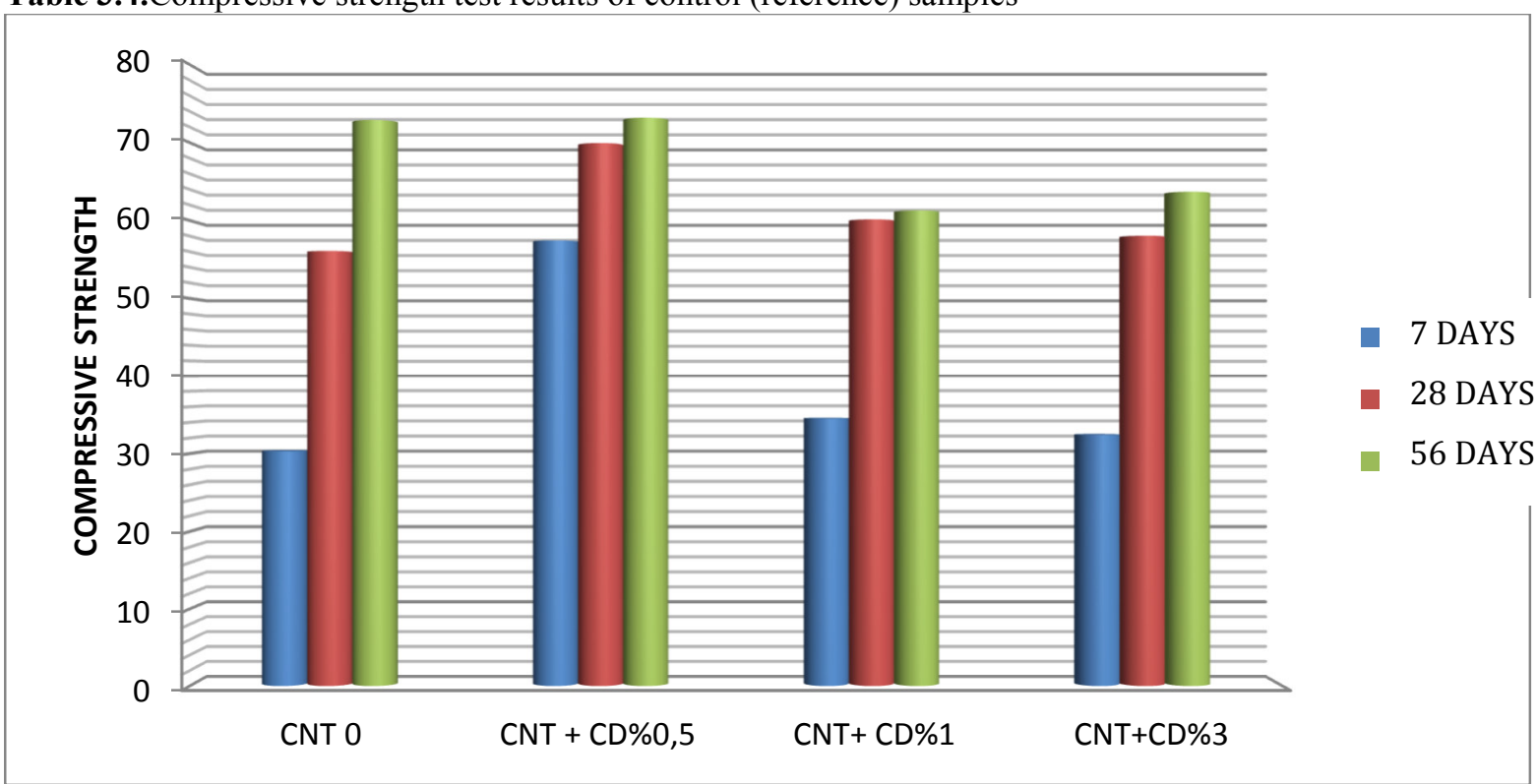

An increase in compressive strength was seen in the $10 \%$ grade $\mathrm{C}$ fly ash sample without carbon powder compared to the reference sample. Although there was an increase in the series with the combination of $0.5 \%$ carbon powder and $10 \% \mathrm{C}$ class fly ash, it was observed that there was a decrease in the compressive strength in the other series (Table 3.5).

Table 3.5.Compressive strength test results of $10 \%$ rated Class $\mathrm{C}$ fly ash and carbon powder combinations.

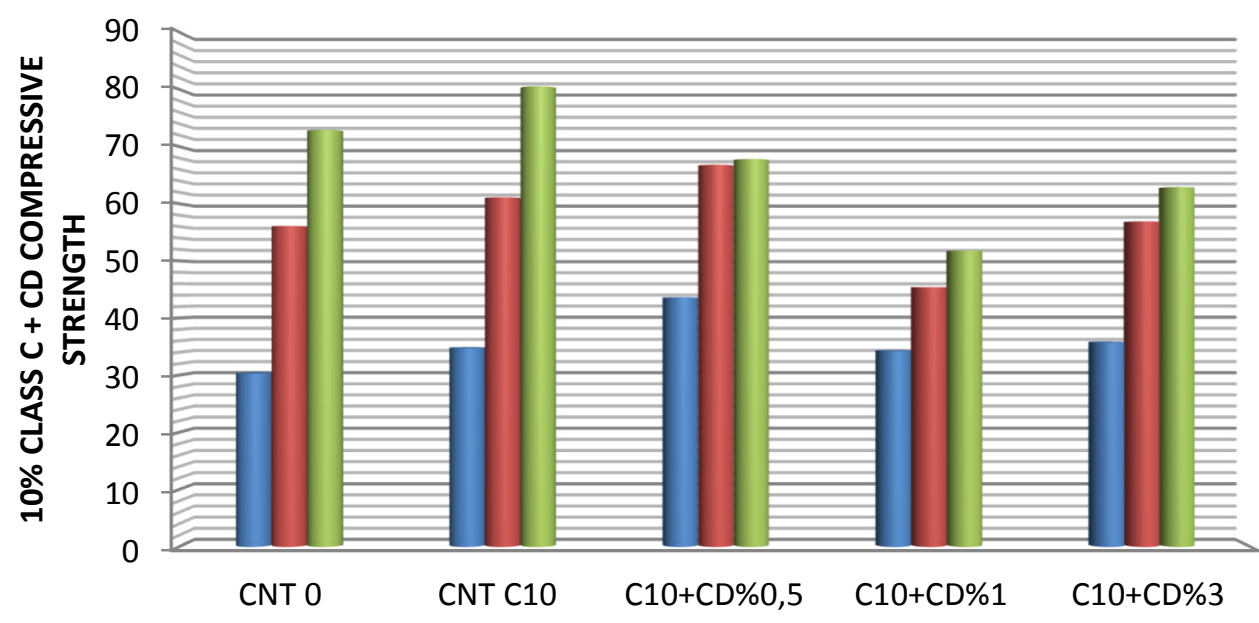

7 DAYS

28 DAYS

56 DAYS

An increase in compressive strength was observed in a Class C fly ash sample with a rate of $20 \%$ without carbon powder compared to the reference sample. Although the $\mathrm{C} 20+\mathrm{CD} 0.5 \%$ sample increased, it was observed that there was a decrease in the compressive strength in the other series (Table 3.6). It has been determined that the carbon powder used more than $0.5 \%$ reduces the compressive strength, despite the $10 \%$ fly ash supplement. 
Table 3.6. Compressive strength test results of $20 \%$ Class C fly ash and carbon powder combinations.

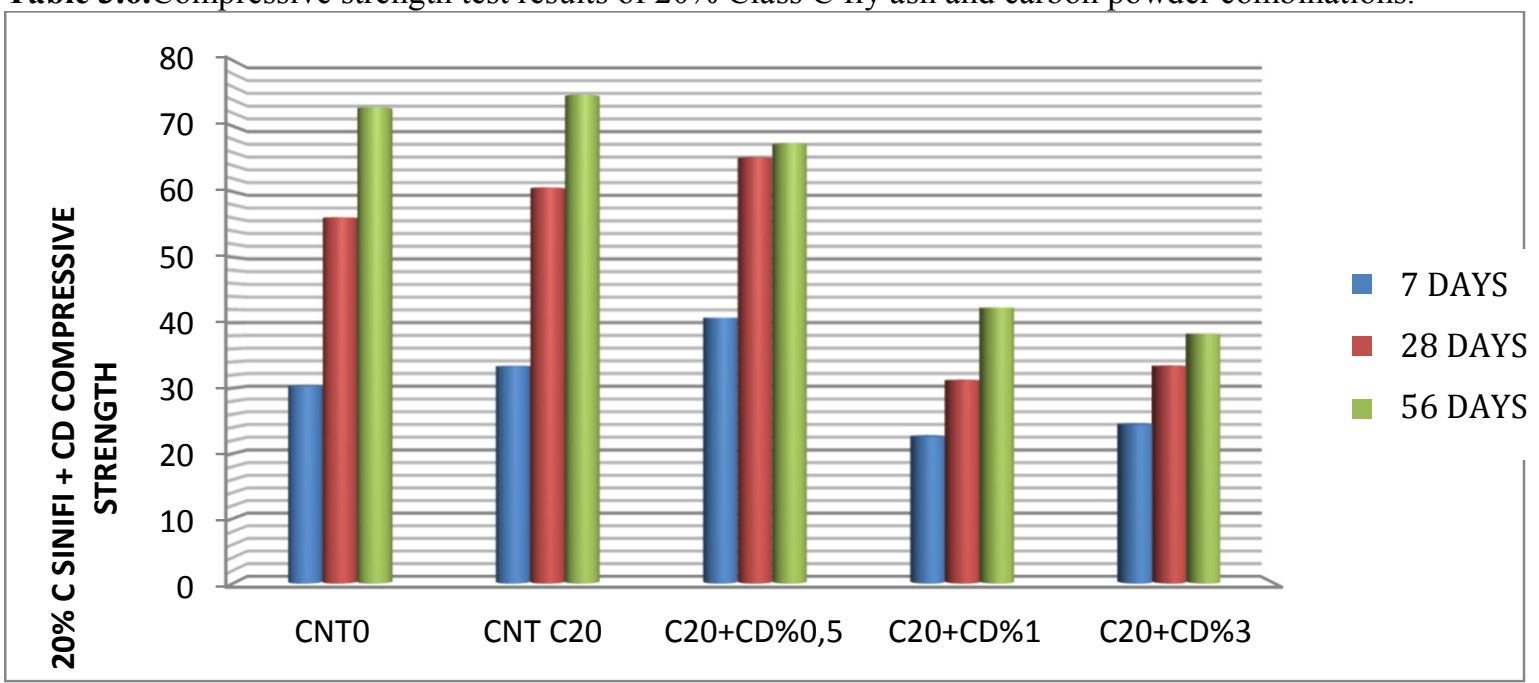

An increase in compressive strength was observed in all series with $10 \% \mathrm{~F}$ class with fly ash carbon powder and carbon powder-free compared to the control sample (Table 3.7). The best result was obtained from the F10 + CD $0.5 \%$ sample.

Table 3.7.Compressive strength test results of $10 \% \mathrm{~F}$ class fly ash and carbon powder combinations.

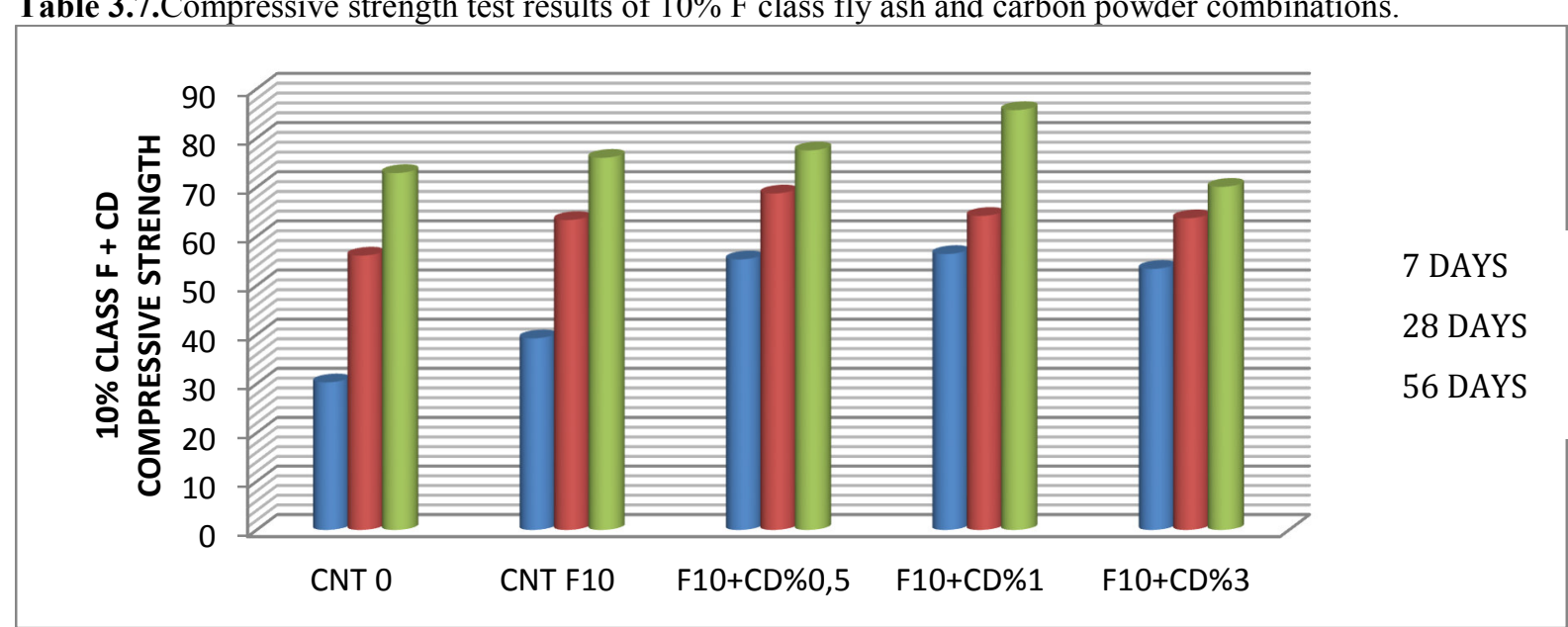

An increase in compressive strength was observed in in $20 \%$ class F class with fly ash carbon powder and carbon powder-free compared to the reference sample except for the F20 + CD 3\% sample (Table 3.8). However, the 7th and 28th day readings of the relevant sample are observed to be increased compared to the reference sample. The best result was obtained from the F $20+$ CD $0.5 \%$ sample. 
Table 3.8.Compressive strength test results of $20 \% \mathrm{~F}$ class fly ash and carbon powder combinations.

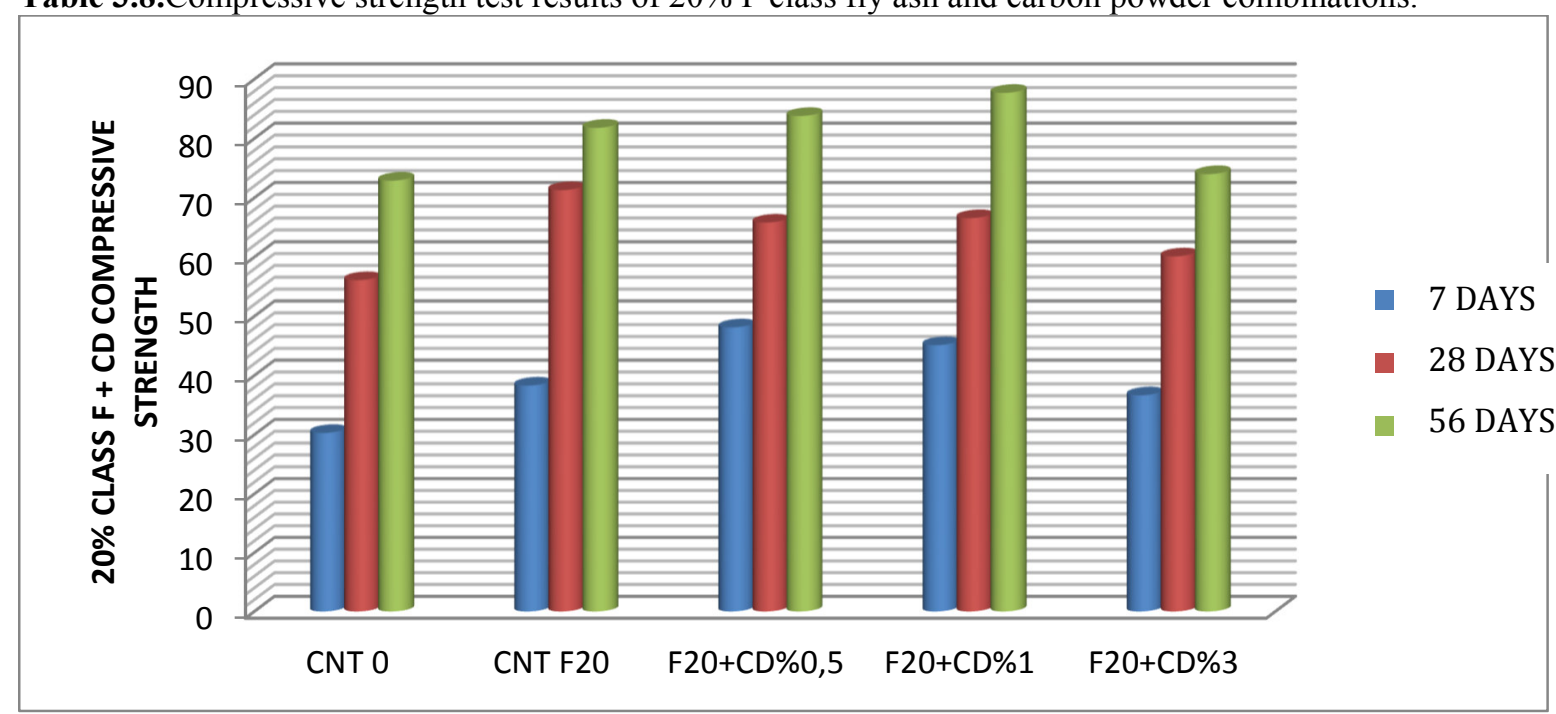

According to the results given in Table 3.9, the most efficient result of $0.5 \%$ by weight of aggregate was obtained in $\mathrm{C}$ class fly ash and carbon powder combinations. In the compressive strength test, the best result was seen in $\mathrm{C} 10+\mathrm{CD} 0.5 \%$ and $\mathrm{C} 20+\mathrm{CD} 0.5 \%$ samples in the $\mathrm{C}$ class fly ash and carbon powder combination series. Table 3.9Compressive strength test results of Class $\mathrm{C}$ fly ash and carbon powder combinations.

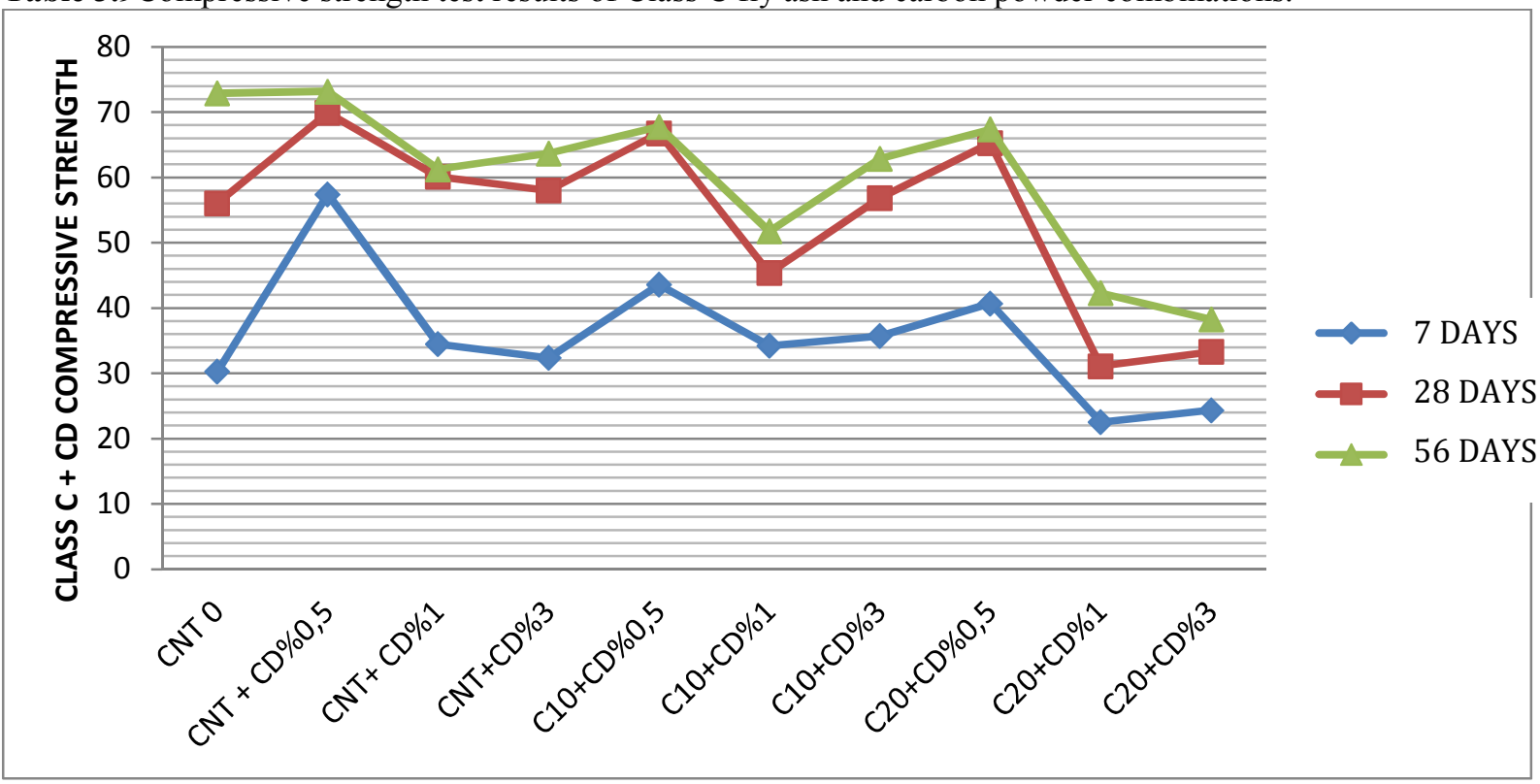

In the compressive strength test, the best results were seen in the F class fly ash and carbon powder combination series in $\mathrm{C} 10+\mathrm{CD} 0.5 \%$ and $\mathrm{C} 20+\mathrm{CD} 0.5 \%$ samples. According to the results given in Table 3.10, the most efficient result of $0.5 \%$ rate by weight of aggregate was obtained in F class fly ash and carbon powder combinations. 
Table 3.10.Compressive strength test results of $F$ class fly ash and carbon powder combinations.

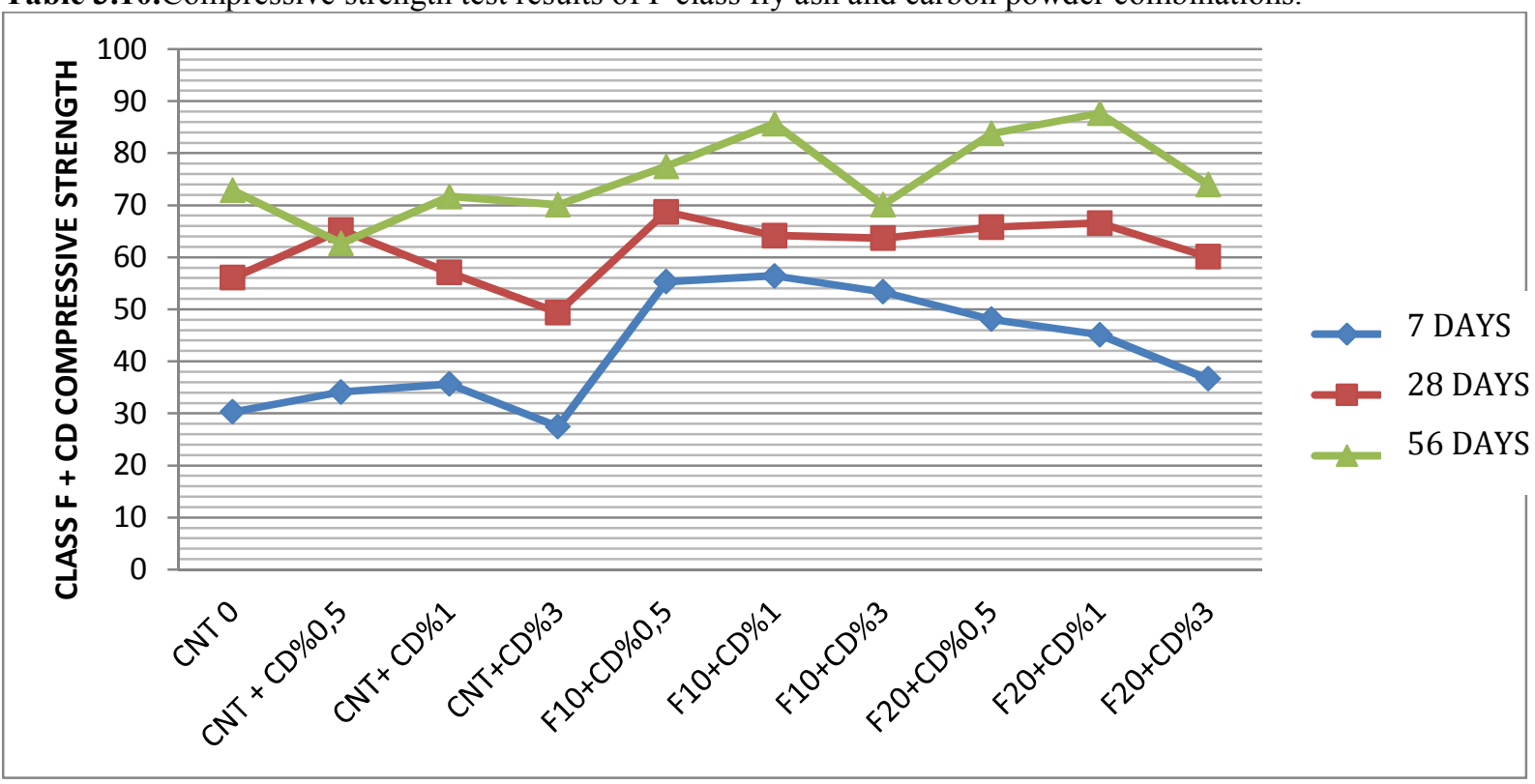

\subsection{Tensile Strength Test Results}

According to the results of the tensile strength test conducted in the series with fly ashless carbon powder, it was determined that there was an increase in the sample with $0.5 \%$ carbon powder compared to the reference sample (Table 3.11). It was observed that there was an increase in 56-day series.

Table3.11.Tensile strength test results on samples with fly ash-free carbon powder

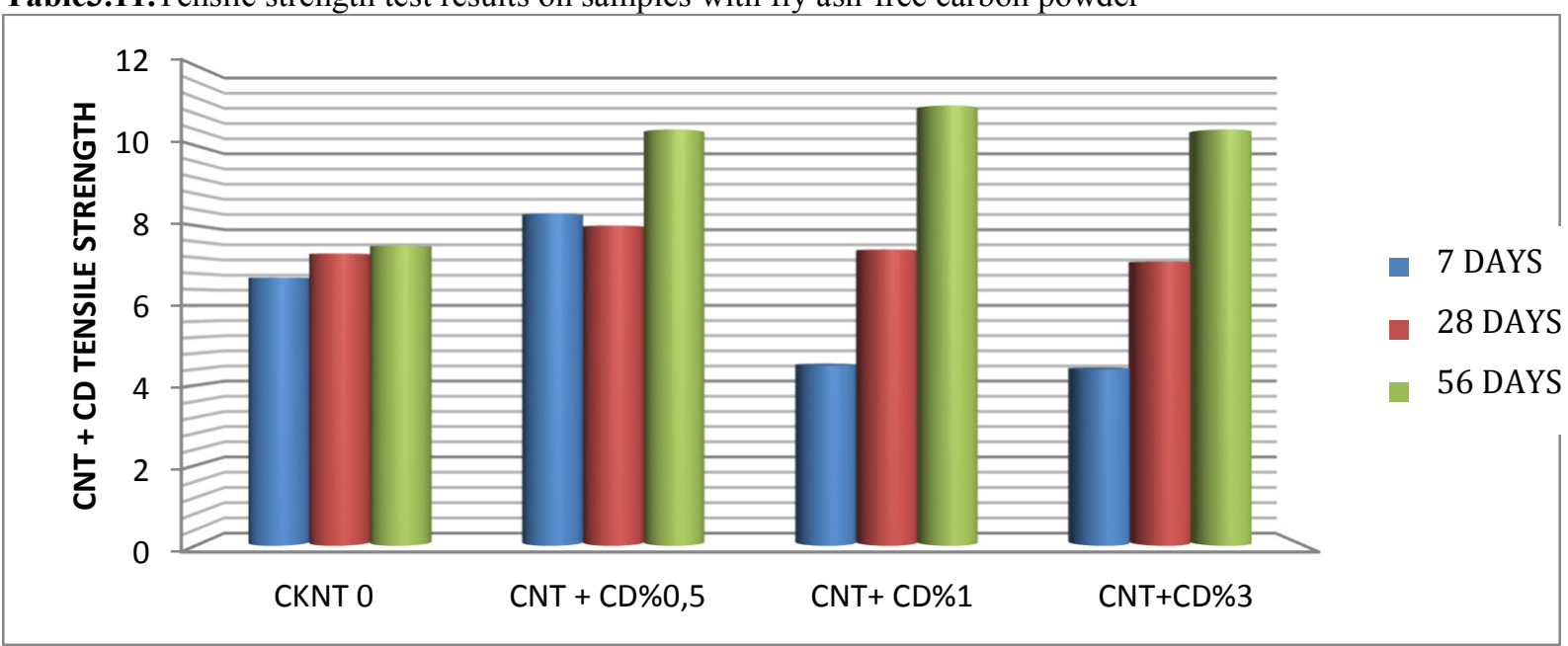

In the $10 \%$ Class $\mathrm{C}$ fly ash series, an increase in the tensile strength of the sample with carbon powder-free was detected. A decrease in tensile strength was found in 7 and 28 day series with $10 \% \mathrm{C}$ class fly ash combination of carbon powder compared to the reference sample (Table 3.12). In the 56-day series, it was concluded that it increased the tensile strength. 
Table 3.12. Tensile strength test results of $10 \%$ Class $\mathrm{C}$ fly ash and carbon powder combinations.

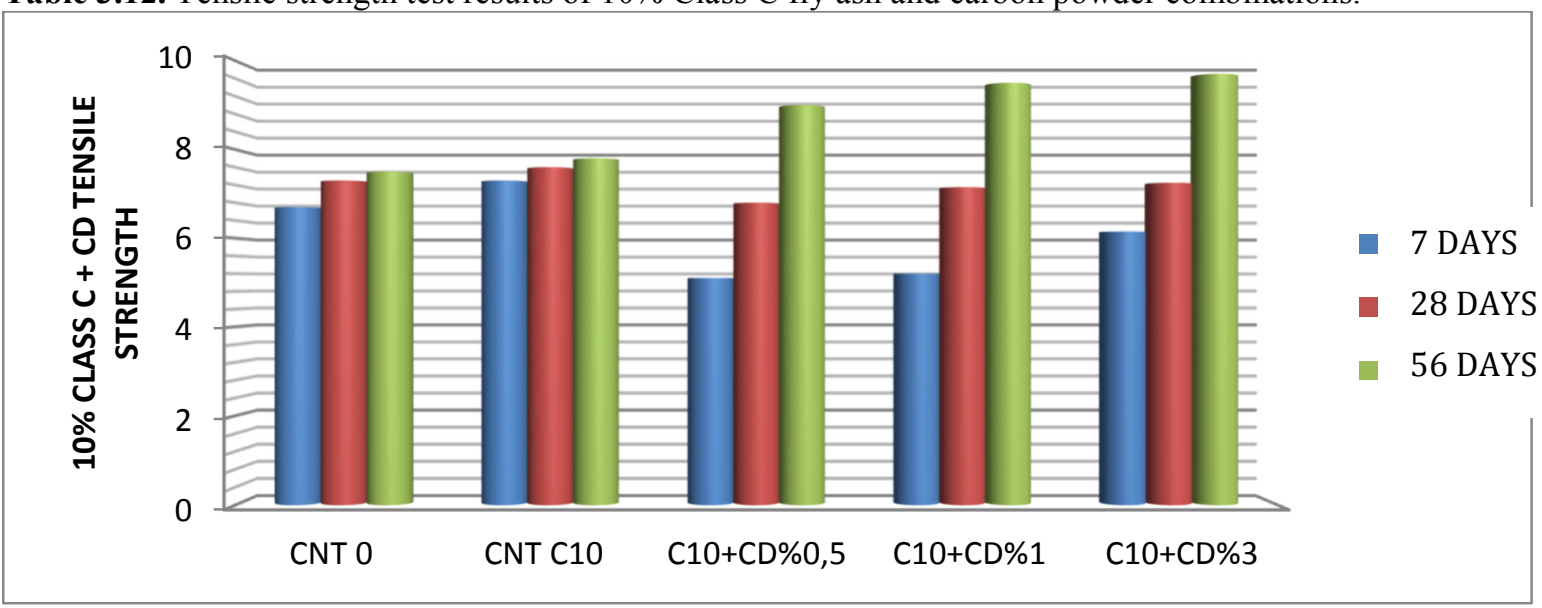

It was determined that there is a decrease in the tensile strength in the $20 \%$ rated class $\mathrm{C}$ fly ash series, the carbon powder-free sample compared to the reference sample, and the tensile strength in the combination series with carbon powder (Table 3.13). C20+CD 1\% sample showed an increase in tensile strength in 56 days of test. Table 3.13Tensile strength test results of $20 \%$ Class $\mathrm{C}$ fly ash and carbon powder combinations.

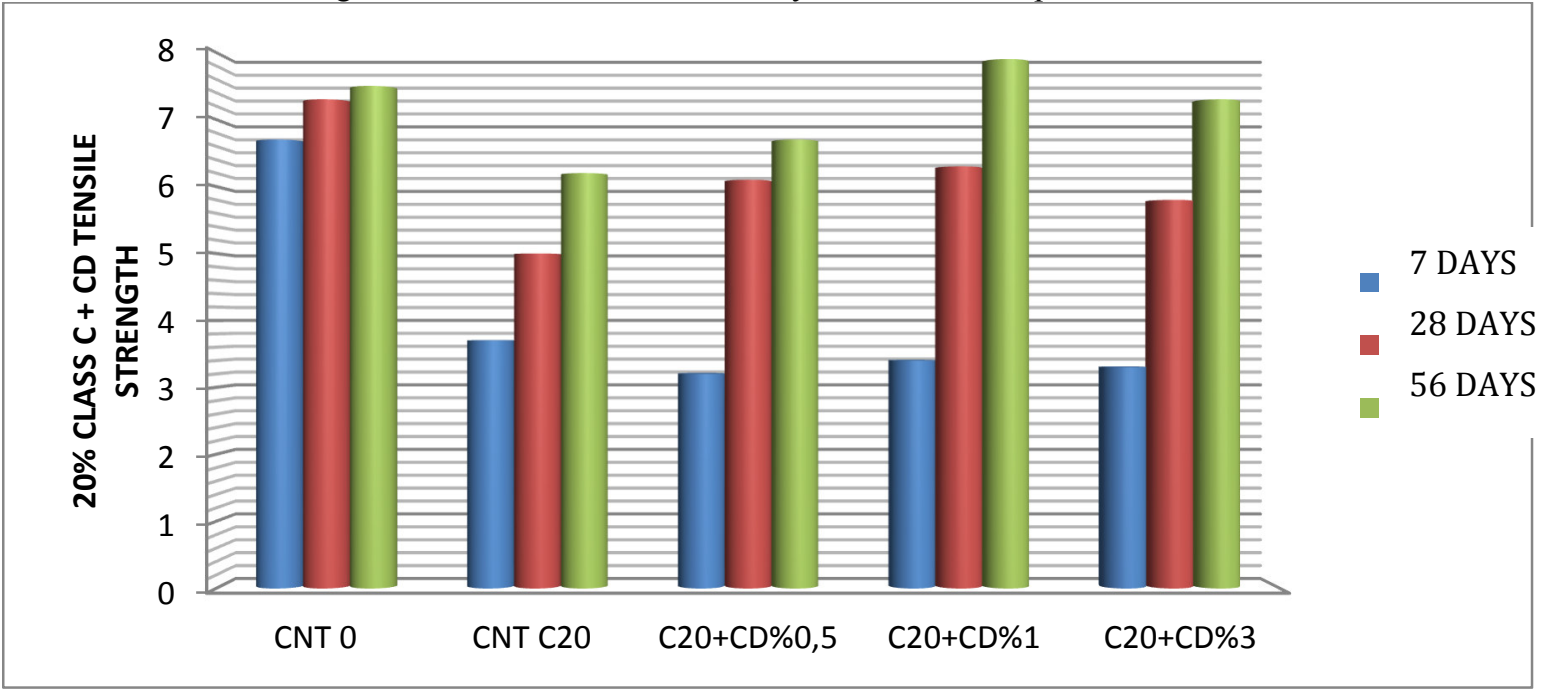

It was observed that there was an increase in the tensile strength of the $10 \%$ rated class $\mathrm{F}$ fly ash series in the carbon powder-free sample. Although the carbon powder caused an increase in the F10 + CD $0.5 \%$ sample, it was found that there was a decrease in the tensile strength in the other series (Table 3.14). An increase in tensile strength was observed in 56-day series. 
Table 3.14 Tensile strength test results of $10 \%$ Class F fly ash and carbon powder combinations.

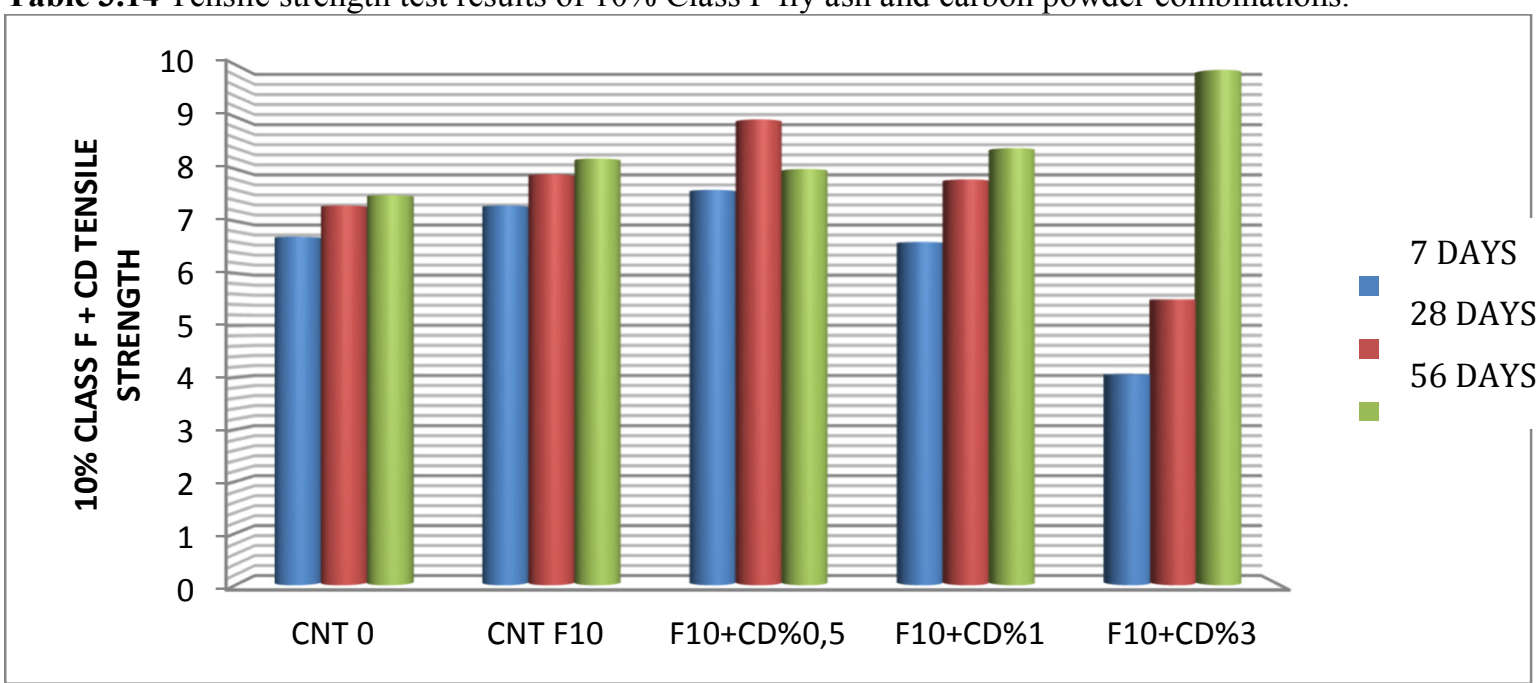

It was seen that there was an increase in the tensile strength of the $20 \%$ rated class F fly ash series in the carbon powder-free sample (Table 3.15). Carbon powder has been found to cause a decrease in tensile strength compared to the reference sample, except for the 56-day series.

Table 3.15 Tensile strength test results of $20 \%$ Class F fly ash and carbon powder combinations.

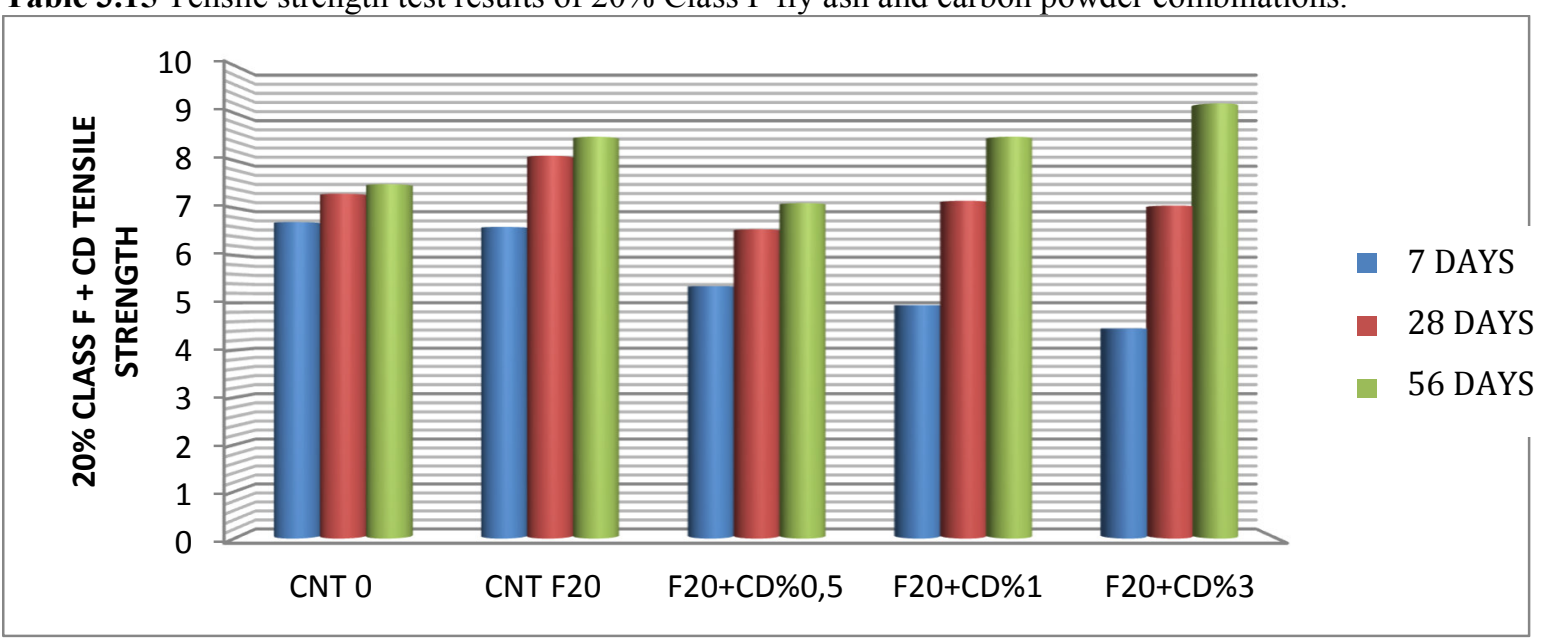

According to the results of the tensile strength test, when the samples with the combination of fly ash and carbon powder were compared, it was seen that the F class with fly ash series (Table 3.16 and Table 3.17) had higher tensile strength compared to the $\mathrm{C}$ class with fly ash series. The best results were seen in $\mathrm{C}$ class fly ash and carbon powder combinations with samples that were used at a ratio of $0.5 \%$ by weight to aggregate. In $\mathrm{F}$ class fly ash and carbon powder combinations, the best results were found in samples that were used at $1 \%$ by weight to aggregate. 
Table 3.16.Tensile strength test results of all series with $\mathrm{C}$ class fly ash and carbon powder

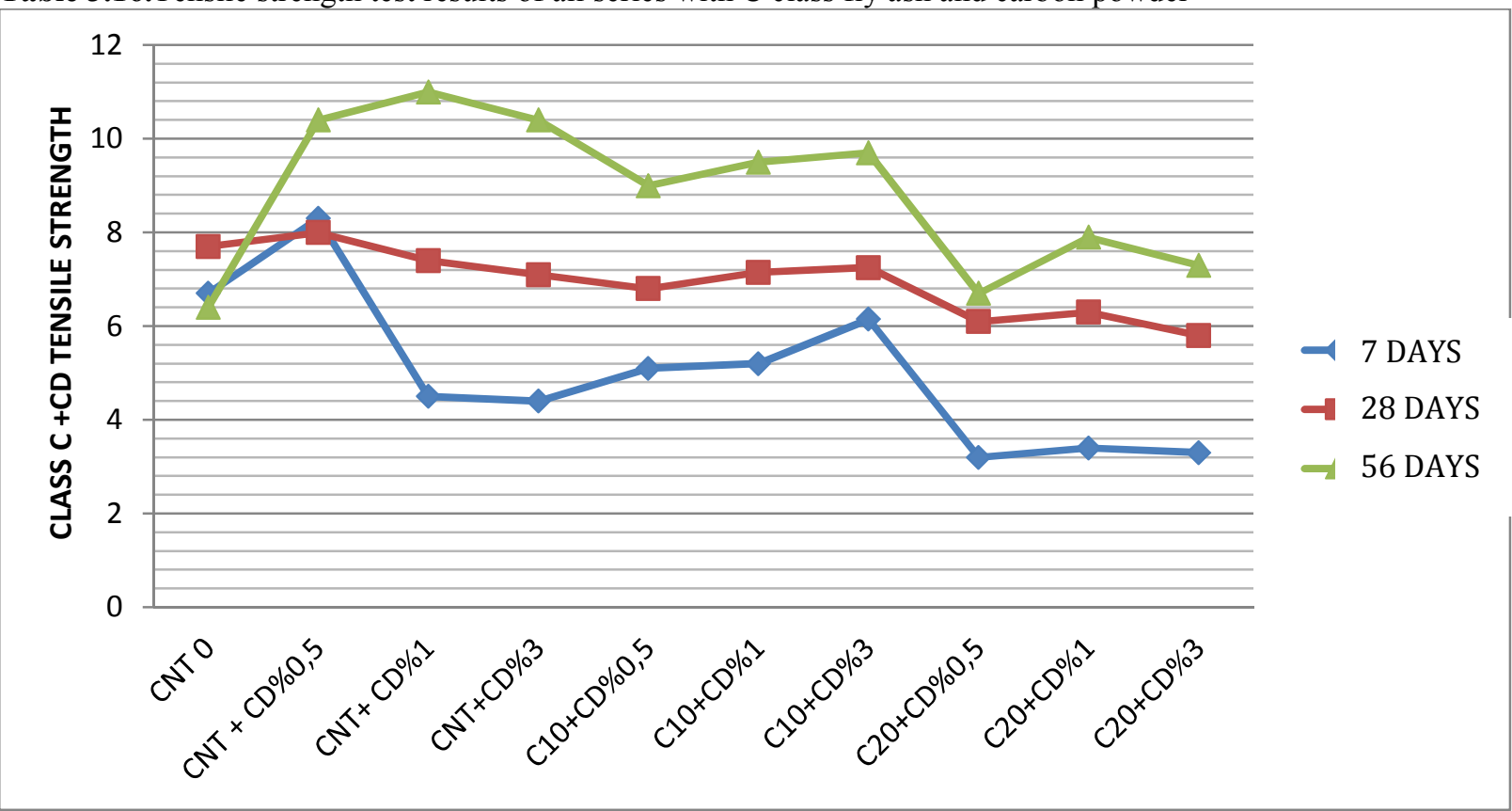

Table3.17. Tensile strength test results of F class fly ash and carbon powder combination samples.

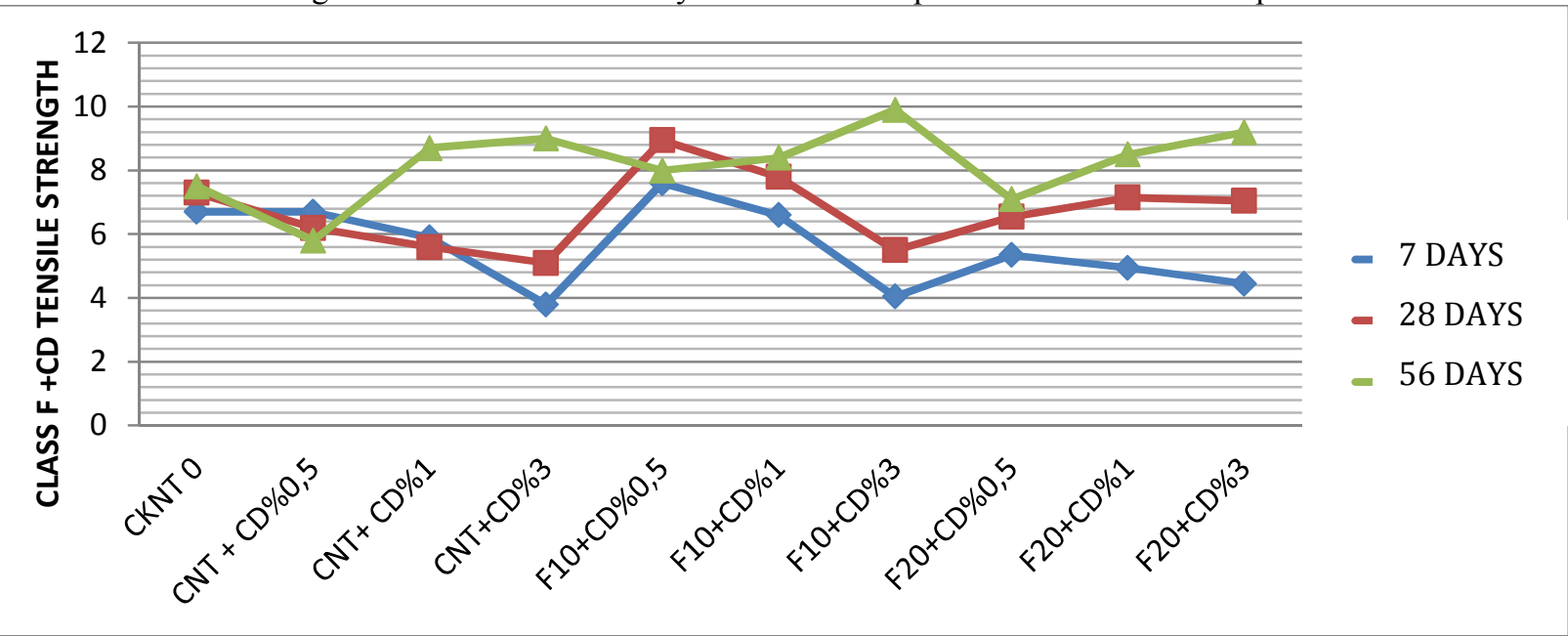

\section{Discussion}

- This study showed that carbon powder increases electrical conductivity in fly ash reinforced mortars used as mineral additives.

- It was seen that $\mathrm{F}$ and $\mathrm{C}$ Class fly ash reinforced mortars improve the compressive and tensile strength.

- F Class (Çayırhan) fly ash and carbon powder combination mortars have been found to improve the compressive and tensile strength compared to the reference sample.

- All of the Class C fly ash and carbon powder series were found to have increased tensile strength in 56day tests.

- Carbon powder, which has a wide floor in the food, mechanical and defence industries, can also be seen to provide effective benefits in the construction sector and is likely to take its place quickly among building materials.

- It has been observed that carbon powder can also provide efficiency in smart concrete targeted structures.

- It has been found that carbon powder can also benefit in structures targeted for conductivity.

- In these days, when global pollution is increasing rapidly, carbon powder used with mineral additives reduces environmental damage.

- The combined use of fly ash and carbon powder ensures affordability compared to other carboncontaining materials. 
Carbon powder provides homogeneous distribution in mortar with granulated structure compared to carbon nano tube and carbon fibres and reduces gaps with micro structure.

\section{References}

ASTM C 618, StandardSpecification for Coal Fly Ash and Raw or Calcined Natural Pozzolan for Use in Concrete, American Society For Testing and Materials, 2008.

Aruntaş H.Y. The potential use of fly ash in the construction industry, Gazi University, Journal of Faculty of Engineering and Architecture, 2006;21 (1): 193-203.

Bertolini, L.,Bolzoni, F., Pastore, T. andPedeferri, P., 2004. Effectiveness of a conductivecementitious mortar anode forcathodicprotection of steel in concrete. CementandConcreteResearch, 34, 681- 694.

Boğa, A.R., (2017)“The Effect of Using Carbon Fibre and Steelmaking Slag on the Mechanical and Electrical Conductivity Properties of Mortars", AfyonKocatepe University, Journal of Science and Engineering Sciences, AKÜ FEMÜBİD XX (201X) 035603 (1066-1075) AKU J. Sci. Eng. XX (201X) 035603 (10661075) DOİ: $10.5578 / \mathrm{fmbd} .66301$.

Chung, D.D.L., 2004. Electrically Conductive Cement Based Materials. Advanced in Cement Research, 26(4), $167-176$

Demirel, B. (2006). The investigation of stress and temperature behaviours of the smart lightweight concrete.

Dehghanpour, H., "Evaluation of Nano Carbon Black Obtained by Pyrolysis Method in Electrically Conductive Concrete" Sakarya University, Institute of Science, Civil Engineering Department, Building Materials Division. May2019.

Gopalakrishnan, K., Ceylan, H., Kim, S., Yang, S. andAbdualla, H., 2015. Electrically Conductive Mortar Characterization for Self Heating Airfield Concrete Pavement Mix Design. International Journal of Pavement Researchand Technology, 8(5), 315-324.

Huang, B.S.,Chen, X.W. andShu, X., 2009. Effects of electrically conductive additives laboratory-measured properties of asphalt mixtures. Journal of Materials in CivilEngineering, 21(10), 612-617.

https://tr.wikipedia.org/wiki/Carl_Wilhelm_Scheele,accessed on 05.03.2021.

H. K. SEZER Et Al., "Additive manufacturing of carbon fibre reinforced plastic composites by fused deposition modelling: effect of fibre content and process parameters on mechanical properties," JOURNAL OF THE FACULTY OF ENGINEERING AND ARCHITECTURE OF GAZI UNIVERSITY , vol.34, no.2, pp.664674, 2019

Jaroniec, M., \&Choma, J. (1986). Characterization of heterogeneity of activated carbons by utilizing the benzene adsorption data. Materials chemistry and physics, 15,521.

Kadlec O. (1979): “TheCharacterization of PorousSolids” ProceedingSwiss-British Symp. SCI, London.

Küçükgül, E. Y. (2004). Commercial activated carbon production and determination of its properties. DokuzEylul University, Faculty of Engineering, Journal of Science and Engineering, 6(3), 41-56.

Morgan, I., \& Fink, C. E. (1989). Activated carbon production. Chem. Ind. Eng, 2, 219.

Stoeckli H. F.,Kraehenbuehl F. (1984): "The External Surface of Microporous Carbons, derived from Adsorption and Immersion Studies", Carbon, 22, 297.

Stoeckli H. F.,Kraehenbuehl F. (1984): "TheExternal Surface of Microporous Carbons, derived from Adsorption and Immersion Studies", Carbon, 22, 297.

Subaşı S. The effect of fly ash substitution on freeze-thaw resistance in Portland composite cement concretes, EJournal of New World Sciences Academy, 2009; 4 (1): 67-76.

TS EN 197-1/March 2002. Cement - Part 1: General Cements - Composition, Properties and Compatibility Criteria. TS EN 196-1 Cement Test Methods - Part 1: Strength Determination, TSE, (2002).

TS EN 197-1/March 2002. Cement - Part 1: General Cements - Composition, Properties and Compatibility Criteria.

TS EN 12350-5, Concrete - Fresh Concrete Tests - Part 5: Spreading Table Test, Turkish Standards Institute, Ankara, Turkey, 2010

Tuan, C.Y., 2004. Conductive Concrete for Bridge Deck Deicing and Anti-icing, Project No. SPR-PL-1(037) P512, Nebraska Department of Roads, July.

Türker, P., Erdoğan, B., Katnaş, F., \&Yeğinobal1, A. (2009). Classification and Properties of Fly Ash in Turkey. Cement Manufacturers' Association of Turkey, 20-34. 


\section{RESUME}

1. Hacer Uzunalioglu (Corresponding author)

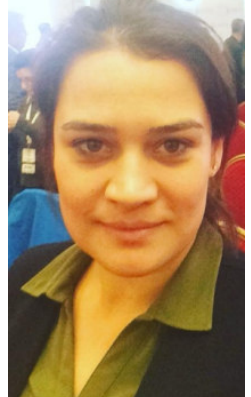

She was born in Bulgaria in 1985

License: Gazi University Technical Education Faculty Building Education Department 2009 ; Aculty of Management Business School, Department of Business 2009.

Graduate Student, Material Science And Engineering, Kastamonu University 2021

She is a student in Gazi University Civil Engineering Department, now.

2. Assist. Prof. Dr. Adem Ahıskalı

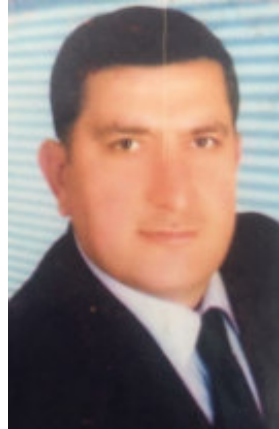

Undergraduate Azerbaijan Architecture and Engineering University.

Post Graduate Transportation Thesis Advisor Yagup Piriyev Ph.D. Gazi University Institute of Science Thesis Advisor Kürşat ÇUBUK.

Yard. Assoc. Dr. Eng. Faculty of Civil Engineering. Department of Transportation U.S.A. 2010

3. Res. Assist. Hakan Caglar

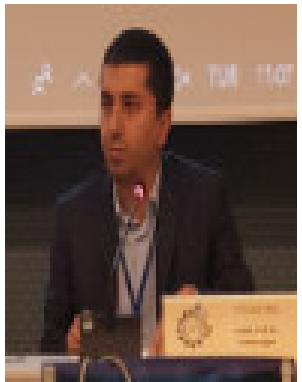

He was born in Kırșehir in 1985.

License: Gazi University Technical Education Faculty Building Education Department (2009), Krrıkkale University Engineering Faculty Civil Engineering Department (2017)

Post Graduate: Sakarya University, Institute of Science, Building Education Department (2011)

Doctorate: Gazi University, Institute of Science, Department of Environmental and Technical Research of Accidents (2016) 
4. Prof. Dr. Salih Yazıcıoglu

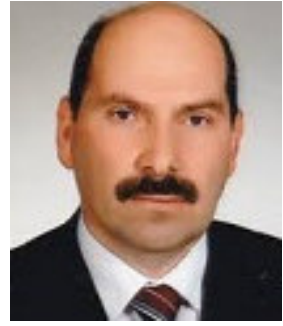

He was born in Rize in 1964.

He completed his primary, secondary and high school education in Rize.

He completed his undergraduate and graduate education at Firat University.

Between 1995-1997 F.Ü. Lecturer in Technical Education Faculty. See. Dr. served as.

In 1997, Dr. Lecturer He was appointed as a member.

He became Associate Professor in 2008 and was appointed to the Associate Professor position of Gazi University Technology Faculty Civil Engineering Department in 2011.

In 2013, he became a Professor at Gazi University Technology Faculty Civil Engineering Department.

Between 1997-2009, he served as the Head of the Restoration Department of the Institute of Science at Firat University and the Deputy Head of the Building Education Department.

Between 2012-2013, he served as Vice President of Gazi University Technology Faculty Civil Engineering Department.

Between 2017-2020, he worked as the Head of the Civil Engineering Department of Gazi University Technology Faculty.

Between 08/06/2020 - 15/11/2020, he worked as the Deputy Dean of the Faculty of Engineering and Architecture at Batman University.

He has many domestic and foreign articles, citations and scientific studies in the field of Building Materials and concrete technologies. As of 01/06/2020, he was appointed as the dean of Batman University Technology Faculty. 